\title{
SUBJECT TEACHERS AND ENHANCEMENT OF STUDENTS' ENGLISH PROFICIENCY IN SELECTED SENIOR SIX CLASSROOMS IN RWANDA
}

\author{
Speciose N. Ndimurugero ${ }^{1}, \&$ Gloriose Mugirase \\ ${ }^{1} \mathrm{Dr}$. \\ University of Rwanda, College of Arts and Social Sciences (Rwanda)
}

\begin{abstract}
This study was conducted in two public and two private secondary Sixth Form schools in Huye District of the Southern Province in Rwanda. The researchers' concern was that most secondary school leavers enter university with low English language proficiency whereas this language is the sole medium of instruction in Rwanda. This lack of competence in English constitutes a hindrance to the students' academic performance. The researchers chose to focus on subject teachers because they are the ones who spend much more time with students as subject-related courses are allotted more hours than English, and they are supposed to support students across the curriculum (Mora-Flores, 2019). Therefore, this study aimed to explore whether subject teachers offered any assistance in helping enhance their students' English proficiency. The study drew on Language across the Curriculum (LAC) approach. LAC stipulates that all teachers are language teachers, that subject teachers and language teachers should work jointly, and that language should be taught across the curriculum (Lughmani, Chan, Gardner, \& Wong, 2017). For validity and reliability purposes, the current study made use of both qualitative and quantitative data collection and analysis methods. Emerging themes from observations and interviews were inductively analysed and numerical data from questionnaires interpreted. The findings of the study revealed that only some of the subject teachers used strategies that could help promote their students' English proficiency. The findings also indicated that content and English language teachers did not collaborate to inform each other on more appropriate ways to scaffold their students' learning, which hindered the latter's acquisition of English skills. In accordance with these findings, recommendations were made.
\end{abstract}

Keywords: English proficiency, subject teachers, teaching strategies, sixth form students, secondary schools.

\section{Introduction}

In Rwanda, the language-in-education policy stipulates that Kinyarwanda, the mother tongue, is the language of instruction from Primary 1 to Primary 3 while English, a second language, is studied as a subject and becomes medium of instruction from Primary 4 onwards. Proficiency in English from Primary 4 is, thus, a prerequisite for Rwandan students to deal with their studies successfully.

However, the researchers' language teaching experience in Rwandan tertiary education is that secondary school graduates admitted at university are not proficient enough in English to cope with their academic subjects delivered in this language. They lack both Basic Interpersonal Communication Skills (BICS) and Cognitive Academic Language Proficiency (CALP) as described by Cummins (2008). The researchers decided to conduct their study in secondary Sixth Form classes where students' success in the end-of-year national examinations determine their admission to higher learning institutions. Furthermore, the researchers' choice of subject teachers as research participants is that in secondary school advanced level (Forms 4, 5 and 6), content subjects are allotted much more time (280 minutes) than English (80 minutes). The researchers, hence, believe that subject teachers should devise strategies to help their students develop proficiency in this language of instruction, which would equally promote their academic performance.

\section{Objectives}

The primary aim of the study was to assess whether subject teachers in the selected schools played any role in the development of their students' proficiency in English. The secondary objectives were to determine (1) whether subject teachers used any learning strategies to promote their students' English 
proficiency, (2) whether they informed English language teachers on suitable material to design for their students, (3) whether English teachers informed subject teachers about how to assist their students to improve their English language skills, and (4) whether the students were proficient in English.

\section{Research design}

The present study used case-study design. Case-study design allows a researcher to conduct an in-depth investigation into a real-life phenomenon and in its real setting (Ridder, 2017). The researchers in this study observed the phenomenon from different subject classrooms in different schools so as to obtain more reliable and more valid data.

\section{Research methodology}

\subsection{Setting and participant selection}

The study was conducted in four secondary schools (two public and two private) in Ngoma Sector, Huye District in the Southern Province of Rwanda. Researchers chose this setting because of the proximity of the schools to their workplace. This allowed them to conduct the study and to fulfill their academic activities at the University of Rwanda, where they are lecturers. For the sake of anonymity, the schools were labeled School 1, School 2, School 3 and School 4. The researchers used purposive sampling and visited Biology and Mathematics classrooms as they were the only common subjects in the four schools. The subject teachers (Biology and Mathematics) from these schools were respectively given the pseudonyms T1 and T2, T3 and T4, T5 and T6, T7 and T8.

\subsection{Research methods}

The researchers made use of both quantitative and qualitative paradigms to gain more understanding of the phenomenon under study. Quantitative approach is used to answer research questions that require statistics, and qualitative approach for questions requiring words (William, 2007). Both approaches enabled them to apply various research techniques. The quantitative method allowed them to administer and obtain data from questionnaires. With the qualitative method, the researchers conducted observations and semi-structured interviews for the sake of data triangulation.

\section{Discussion}

The findings emerging from the research data provided answers to the research questions. The predominating learning strategies used were pair and group discussions and presentations, question-answer technique, teacher talk, and code-switching. Pair and group discussions normally allow students to engage in peer interactions wherein the more knowledgeable students scaffold their group mates with low English skills. For peer interactions to be effective, teachers have to monitor the group activities and make sure everybody is involved. During classroom observations, the researchers noted that only some teachers (T1, T2, T3, T4, and T6) managed the group activities well.

Presentations are another learning technique that promotes students' confidence, their ability to exchange ideas in the target language and their critical thinking ability (Brooks, 2015). In T1's, T2's, T3's, T4's, T5's and T6's classrooms, group discussions resulted in interactive presentations. This was not the case in T7's and T8's classrooms where students had difficulties expressing themselves in English. Both T7 and T8 should have tried various activities requiring students' interactions in English.

The question-answer technique is normally used by teachers to test their students' knowledge and understanding of lessons. These should mostly be questions that stir up students' critical thinking and problem solving skills. However, questions that most of the subject teachers put to their students were not challenging and did not give them enough opportunities to express their thoughts in English. The teachers should also have given their students more opportunities to ask questions using English.

Researchers observed that teacher-talk was another dominant technique that was used by six teachers (T3, T4, T5, T6, T7 and T8). Lei (2009) argues that teacher talk can have good or bad impact on students' communication depending on the quality rather than on the quantity of talk. He explains that good teacher talk should foster students' communicative interactions in class. Nevertheless, these teachers' questions did not aim at promoting the students' communicative skills but rather tested their understanding of the course content.

The triangulated data indicate that teachers and students also made use of the code-switching practice. In a bilingual or multilingual environment, code-switching appears to be a natural phenomenon that helps in raising students' voice, that is, in incorporating their input into the lesson (Alam \& Ghani, 2020). In the observed classrooms, some teachers shifted to Kinyarwanda to make their students understand 
better while a number of students also used this mother tongue during group discussions to negotiate meaning and construct common knowledge. However, code-switching should not be overused as it would hamper acquisition of the target language.

Collaboration between subject and English language teachers was lacking. This constituted a hindrance to the development of students' English proficiency. As far as students' English proficiency was concerned, four teachers (T1, T2, T4, and T5) confirmed that they were satisfied. Most students also affirmed they had good English skills while answering the questionnaires. However, findings emerging from classroom observations and students' interviews disclosed that many students had difficulties understanding teachers' explanations, interacting and writing in English.

\section{Conclusions}

The research findings showed that the main strategies used in the visited subject classrooms were pair and group discussions, presentations, question-answer technique, teacher-talk, and code-switching. In some classrooms, these techniques were properly used whereas they were not in others

De Vos, Strydom, Fouche, and Delport (2002) purport that limitations are unavoidable in any research. The current study also had imitations in scope and time. The researchers wished the study to be conducted in more than four schools, to observe more subject classrooms, and for a longer period of time, yet their tight teaching workload and little availability of secondary Sixth Form students were an impediment.

\section{Recommendations}

Content-subject teachers should feel concerned about their students' proficiency in English and use appropriate strategies to allow them to both acquire knowledge of scientific concepts and develop their English skills. The Rwanda Ministry of Education should organize trainings on how subject teachers can help students develop their English skills and increase the hours allocated to the English course in secondary advanced level classrooms. Further research should also be conducted in English language classrooms to explore whether teachers help promote their students' basic interpersonal communication skills and cognitive academic language proficiency.

\section{References}

Alam, M., \& Ghani, M. (2020). Code-Switching in Pakistani English and Science classrooms. Dilemas Contemporáneos: Educación, Política y Valores, 7 (2).

Cummins, J. (2008). BICS and CALP: Empirical and theoretical status of the distinction. Encyclopedia of language and education, 2 (2), 71-83.

De Vos, A., Strydom, H., Fouche, C. B., \& Delport, CSL. (2002). Research at grass roots: for the social sciences and human service professions. $2^{\text {nd }}$ ed. Pretoria: Van Schaik Publishers.

Lei, X. (2009). Communicative teacher talk in the English classroom. English Language Teaching, 2 (1).

Lughmani, S. D., Gardner, S., Chen, J., Wong, H., \& Chan, L. (2016). English across the curriculum: Fostering collaboration. In Negotiating diversity in English language teaching: A tragedy in four acts. ELTWO: Special Issue on 5th CELC symposium proceedings.

Mora-Flores, E. (2017). Integrated English language development: Supporting English learners across the curriculum. Huntington Beach: Shell Educational Publishing Inc.

Ridder, H. G. (2017). The theory contribution of case study research designs. Business Research, 10 (2), 281-305.

Williams, C. (2007). Research methods. Journal of Business and Economics Research, 5 (3). 